Journal Of Islamic Management

Vol. 1, No. 2, Juli 2021

E-ISSN: 2774-3365

Journal hompage http://jurnalfdk.uinsby.ac.id/index.php/JIM

\title{
Manajemen Pengorganisasian Dakwah : Strategi Lembaga Dakwah MWC NU Kaliwungu Dalam Mengatasi Tantangan Globalisasi
}

\author{
Nur Aenatul Khoria \\ UIN Walisongo Semarang \\ Email: aenatuln@gmail.com
}

\begin{tabular}{l} 
Article Info \\
\hline Article history: \\
Received 15 Februari 2021 \\
Accepted 15 Mei 2021 \\
Published 22 Juli 2021 \\
Page : 109 - 123
\end{tabular}

Keyword:

Manajemen

Pengorganisasian

Dakwah, Strategi dakwah,

Tantangan Globalisasi.

\begin{abstract}
This study aims to determine the management of the da'wah organization at MWC $N U$ Kaliwungu and the strategy of the $N U$ da'wah institution in overcoming the challenges of globalization. This study uses a da'wah science approach that focuses on the management principles of the da'wah organization. The data collection was obtained through an interview and library process that utilized reference sources in the form of books, journals, and other articles, both printed and online. Data analysis followed the Miles and Huberman model. The results of this study indicate that: First, the management of da'wah organization at MWC NU Kaliwungu in developing its da'wah tasks applies organizational management based on the forms of division of tasks. Second, the da'wah strategy carried out by MWC NU Kaliwungu in the face of the global industrial market which has begun to penetrate the Kaliwungu area which is marked by the establishment of KIK (Kendal Industrial Area), is more focused on reinforcing the teachings of NU's and Aswaja's to the public. . Therefore, the scholars developed a da'wah strategy through mental and spiritual strengthening activities with 1 billion sholawat with the community in each branch, held Lailatul Ijtima' regularly with religious leaders in the KaliwunguKendal area, and used the media for da'wah by establishing cooperation with Radio Citra Kendal to be transferred to the MWC NU Da'wah Building.
\end{abstract}

Penelitian ini bertujuan untuk mengetahui manajemen pengorganisasian dakwah di MWC NU Kaliwungu dan strategi lembaga dakwah NU dalam mengatasi tantangan globalisasi. Penelitian ini menggunakan pendekatan ilmu dakwah yang terfokuskan pada prinsip manajemen pengorganisasian dakwah. Pengumpulan data diperoleh melalui proses wawancara dan kepustakaan yang memanfaatkan sumber referensi buku, jurnal dan artikel cetak maupun online. Analisis data mengikuti model Miles dan Huberman. Hasil penelitian menunjukkan bahwa: Pertama, manajemen pengorganisasian dakwah di MWC NU Kaliwungu dalam mengembangkan tugastugas dakwahnya menerapkan manajemen pengorganisasian berdasarkan bentukbentuk pembagian tugas. Kedua, strategi dakwah yang dilakukan MWC NU Kaliwungu dalam menghadapi pasar industri global yang mulai merambah di wilayah Kaliwungu yang ditandai dengan berdirinya KIK (Kawasan Industri Kendal), lebih bersifat kepada penguatan kembali ajaran ke-NU-an dan ke-Aswajaan kepada masyarakat. Oleh karena itu, para ulama menyusun strategi dakwah melalui kegiatan penguatan mental dan spiritual dengan 1 Miliyar Sholawat bersama masyarakat di msing-masing ranting, mengadakan Lailatul Ijtima'secara berkala bersama para tokoh pemuka agama di wilayah Kaliwungu-Kendal, dan pemanfaatan media dakwah dengan menjalin kerjasama dengan Radio Citra Kendal untuk dialih tempatkan di Gedung Dakwah MWC NU.

Copyright (C) 2021 Journal Of Islamic Management

\section{Editorial Office:}

Program Studi Manajemen Dakwah, Fakultas Dakwah dan Komunikasi, UIN Sunan Ampel Surabaya.

Jl. Ahmad Yani 117 Surabaya, Jawa Timur, Indonesia.

Email: jim@uinsby.ac.id 


\section{Pendahuluan}

Dakwah merupakan salah satu fenomena sehari-hari yang dapat dinikmati oleh masyarakat Islam di Indonesia. Perkembangannya yang semakin menjamur, menjadikan dakwah sebagai suatu aktivitas untuk mengajak, menyeru, dan mengundang manusia dengan misi keagamaan amar ma'ruf nahi mungkar. Hal ini dilakukan sebagai usaha membentuk kesadaran masyarakat islam yang taat terhadap ajaran agama yang dirisalahkan oleh Nabi Muhammad Saw. Tujuannya adalah untuk kebahagiaan manusia baik dalam kehidupan di dunia sekarang ini, maupun dalam kehidupan di akhirat nanti.

Machasin (2015: 13) mengemukakan bahwa proses dakwah itu sendiri bukan sekedar tabligh atau penyampaian pesan agama islam kepada mad'u, bukan sekedar khutbah, bukan pula sekedar proses pendidikan dan pengajaran agama islam, tetapi dakwah sebagai proses pembentukan kepribadian islami yang pada gilirannya akan melahirkan peradaban manusia yang memiliki karakter imani, islami dan ihsani. Disisi lain, perkembangan teknologi yang semakin meruyak dengan disertai arus globalisasi yang tak terbendungkan menjadikan tantangan tersendiri bagi pegiat dakwah dalam menghadapi zaman di era sekarang.
Ahmad (2014: 323) dalam penelitiannya mengemukakan bahwa dewasa ini tantangan dakwah islam tersebut berkaitan dengan akses globalisasi dan kenyataan pluralitas agama. Kemajuan IPTEK yang pesat telah mentransformasikan peradaban manusia dari kultur pertanian ke industri. Godaan dunia dan permasalahan umat yang semakin kompleks, mengharuskan praktisi dakwah untuk memberikan alternatif pemecahan masalah secara efektif dan efisien.

Aktivitas dakwah dapat dikatakan berjalan secara efektif bilamana tujuan dakwah yang diharapkan dapat terwujud. Secara otomatis, sebagai upaya mempermudahkan pencapaian tujuan dakwah maka diperlukan suatu lembaga atau badan otonom (organisasi) untuk mengelola dan mengatur dinamisasi aktivitas dakwah. Tentunya, prinsipprinsip manajemen dapat diterapkan oleh lembaga dakwah sebagai suatu strategi dakwah yang mumpuni untuk menghadapi berbagai macam tantangan zaman. Sehingga dapat memberikan dampak terhadap citra (image) profesionalitas seorang da'i dalam mengemban tugas dakwahnya di tengah kemajemukan sosial dan kecanggihan teknologi di masa kini.

Pentingnya pengorganisasian lembaga dakwah perlu didukung dengan startegi 
dan metode dakwah yang terstruktur. Munir dan Ilahi (2006: xii) menyatakan, apabila komponen dakwah (da'i, mad'u, materi dan media) diolah dengan unsuunsur manajerial atau 'amaliyyah al idariyyah yang terarah maka akan mewujudkan satu kesatuan yang utuh meliputi Takhthith (perencanaan strategi), Thanzhim (pengorganisasian), Tawjih (penggerakan), dan Riqabah (pengawasan atau evaluasi).

Adapun konteks kegiatan dakwah menurut Rosyad Shaleh (1997: 48) dalam penelitian Alfian (2018: 72) menjelaskan bahwa dengan perencanaan, penyelenggaraan dapat berjalan secara terarah atau terorganisir dengan baik. Kemudian, langkah awal dalam pelaksanaan rencana proses dakwah yaitu perlunya membentuk pengorganisasian yang rapi, teratur dan sistematis guna memudahkan pendistribusian tugas-tugas dakwah (Hamriani, 2013: 240). Pada proses pengorganisasian ini akan menghasilkan sebuah rumusan struktur organisasi serta pendelegasian wewenang dan tanggung jawab. Sehingga mewujudkan organisasi dakwah yang akan membentuk spesialisasi kerja, departementalisasi dakwah, rantai komando, rentag kendali, sentralisasi dan desentralisasi, serta formalisasi dakwah (Munir dan Ilahi, 2006: 12-132).
Pusat perhatian penulis kali ini tertuju kepada salah satu lembaga dakwah yang merupakan bagian dari struktur organisasi NU yang sering disebut Majelis Wakil Cabang Nahdlatul Ulama (MWC NU) yang berkedudukan di tingkat kecamatan. MWC NU Kaliwungu merupakan salah satu organisasi NU yang berkedudukan di tingkat kecamatan di kabupaten Kendal yang masih terjaga eksistensinya dalam melestarikan, mengembangkan dan mengamalkan ajaran islam Ahlussunnah wal Jamaah. Pada khususnya, MWC NU Kaliwungu menjadi penggerak dakwah amar ma'ruf nahi munkar dengan menganut ajaran islam yang berdasarkan empat madzab untuk terwujudnya masyarakat Kaliwungu yang demokratis, berkeadilan, dan demi kesejahteraan umat di wilayah Kaliwungu serta wilayah kabupaten Kendal pada umumnya.

Secara historis, Kaliwungu berperan sebagai kecamatan perbatasan yang menjadi wajah pertama cerminan kabupaten Kendal. Hal ini yang menjadikan keresahan dan kekhawatiran para tokoh masyarakat yang tergabung dalam kepengurusan MWC NU Kaliwungu. Pasalnya, mengingat pasar industri global yang mulai merambah di wilayah Kaliwungu yaitu berdirinya KIK (Kawasan Industri Kendal) akan berpotensi menimbulkan peluang 
masuknya kebudayaan barat yang lebih bebas tanpa adanya filterasi apabila tidak berbanding lurus dengan penguatan nilainilai keagamaan. Disisi lain, identitas Kaliwungu yang notabene Kota Santri akan luntur, tradisi khas dan budaya kental di Kaliwungu di rasa akan punah jika tidak tetap dipertahankan. Oleh karena itu, melalui wadah organisasi MWC NU para ulama sebagai subjek dakwah (da'i) harus mengorganisasikan strategi dakwah yang lebih efektif dan efisien dalam menghadapi tantangan globalisasi.

Berdasarkan argumentasi di atas, tulisan ini bertujuan untuk mengetahui manajemen pengorganisasian dakwah MWC NU Kaliwungu dan strategi lembaga dakwah NU dalam mengatasi tantangan globalisasi.

\section{Kajian Pustaka}

Dalam rangka menghindari plagiasi, berikut ada beberapa kajian penelitian terdahulu yang memiliki relevansi dengan penelitian ini:

Pertama, Ahmad Misbahul Anam (2019) jurnal tentang Peran Organisasi dalam Dakwah. Penelitian ini bertujuan untuk mengetahui peran organisasi dalam dakwah. Metode yang digunakan adalah kualitatif. Hasil temuan penelitian ini menunjukan bahwa peran organisasi LDII dalam dakwah sebagai dinamisator, konsolidator, komunikator, peredam konflik sosial serta eksistensialisme simbolik. Dalam pembahasannya, peneliti menggunakan pendekatan peran sebagai sarana membedah obyek kajian.

Kedua, Hamriani, H.M (2013) jurnal tentang Organisasi dalam Manajemen Dakwah. Penelitian ini bertujuan untuk mengetahui langkah pengorganisasian dalam proses dakwah. Adapun hasilnya menunjukan bahwa terdapat 4 (empat) langkah pengorganisasian dalam proses dakwah yang tersusun dari pola atau bentuk kerjasama dakwah, dimana masingmasing orang yang mendukung usaha kerjasama untuk mengetahui pekerjaan apa yang harus dilaksanakan, sampai sejauh mana wewenang masing-masing serta jalinan hubungan antara satu dengan yang lain dalam rangka usaha kerjasama.

Ketiga, Hasan Basri (2016) jurnal tentang Manajemen Organisasi Dakwah. Penelitian ini bertujuan untuk mencermati fenomena keberadaan organisasi islam di tengah umat islam. Hasil penelitiannya menunjukan bahwa keberadaan organisasi Islam yang eksis di tengah umat Islam, dapat kategorikan menjadi empat macam, yakni: organisasi maslahiyah, organisasi ruhiyah/spiritual, organisasi nasional dan organisasi ideologis.

Keempat, Novi Maria Ulfah (2015) jurnal tentang Strategi dan Manajemen Dakwah Lembaga Dakwah Islam 
Indonesia (LDII) Kecamatan Tugu Kota

Semarang. Tujuan penelitian ini untuk mengetahui strategi dan manajemen yang digunakan Lembaga Dakwah Islam Indonesia Kecamatan Tugu Kota Semarang. Adapun metode yang digunakan adalah wawancara dan studi kepustakaan. Temuan hasil penemuannya meliputi strategi dan manajemen yang baik dalam melaksanakan dakwah islam. Adapun strateginya terfokus pada bidang keagamaan, olahraga dan pengkaderan.

Kelima, penelitian oleh Darojah (2016) tentang Startegi Dakwah Majelis Taklim Istighotsah MWC NU Kecamatan Wonotunggal Kabupaten Batang. Penelitian ini bertujuan untuk mengetahui strategi dakwah yang diterapkan pada Majelis Taklim Istighasah MWC NU Wonotunggal di Batang, juga untuk mengetahui faktor pendukung dan penghambat kegiatan dakwah Majelis Taklim Istighasah MWC NU Wonotunggal di Batang. Metode penelitian menggunakan jenis penelitian kualitatif deskriptif melalui wawancara, observasi dan dokumentasi.

Hasil penelitian menunjukkan bahwa: (1) Strategi dakwah yang diterapkan pada Majelis Taklim Istighasah MWC NU Wonotunggal di Batang menggunakan strategi tilawah dan ta'lim sebagai strategi yang tepat diperlukan untuk kegiatan dakwah yang disesuaikan degan kebutuhan masyarakat. (2) Faktor pendukung kegiatan dakwah MWC NU Wonotunggal di Batang, meliputi: adanya arahan dari PCNU, adanya bantuan dari ranting, adanya tanggungjawab dan loyalitas yang baik dari pengurus, banyaknya tokoh masyarakat yang mengikuti, dukungan pemerintah desa, antusiasme masyarakat dan terdapat sistem kekeluargaan dalam kegiatan dakwah yang dilakukan oleh MWC NU Wonotunggal di Batang. Kemudian faktor penghambatnya, meliputi: kegiatan dakwah yang dilakukan terkadang dimanfaatkan oleh kepentingan tertentu seperti politik yang mengganggu keharmonisan kegiatan dakwah di MWC $\mathrm{NU}$, adanya aliran syiah yang masuk di wilayah NU yang menyebabkan kegiatan dakwah MWC terganggu, dan lokasi kegiatan dakwah yang terkadang sulit diakses, sehingga menjadikan masyarakat enggan mengikuti kegiatan dakwah di MWC NU Wonotunggal, Batang.

Berdasarkan uraian relevansi di atas, menurut hemat penulis sejauh ini berbeda dengan permasalahan yang dikaji yakni berkaitan dengan manajemen pengorganisasian lembaga dakwah dan strategi dakwah yang berobjek pada MWC NU Kecamatan Kaliwungu. Melihat dari kajian pustaka terdahulu, peneliti menuturkan bahwa secara permasalahan, 
metode, pendekatan dan topik yang dikaji berbeda.

\section{Metode Penelitian}

Jenis penelitian ini adalah kualitatif deskriptif. Penelitian ini bermaksud memahami fenomena yang terjadi secara alamiah (Moelong, 2016: 6) dengan mengumpulkan data brerupa kata-kata untuk mendeskripsikan permasalahan ang terjadi (Sudaryono, 2019: 88). Penelitian ini menggunakan pendekatan ilmu dakwah yang terfokuskan pada prinsip manajemen pengorganisasian dakwah yang digunakan untuk mengetahui strategi dakwah dalam mengatasi tantangan globalisasi di MWC NU Kaliwungu.

Pengumpulan data diperoleh melalui proses wawancara dan kepustakaan yang memanfaatkan sumber referensi berupa buku, jurnal dan artikel lainnya baik cetak maupun online. Analisis data mengikuti model Miles dan Huberman dalam Sugiyono (2018: 334-343) yang terbagi dalam tahap data reduction (merangkum), data dsiplay (penyajian data) dan conclusion drawing atau verification (kesimpulan).

\section{Hasil dan Pembahasan}

Hasil dan pembahasan berisi hasil-hasil temuan penelitian dan pembahasannya. Tuliskan temuan-temuan yang diperoleh dari hasil-hasil penelitian yang telah dilakukan dan harus ditunjang oleh datadata yang memadai. Hasil-hasil penelitian dan temuan harus bisa menjawab masalah yang dikaji sebagaimana dicantumkan di bagian pendahuluan.

\section{Manajemen}

Pengorganisasian

\section{Dakwah MWC NU Kaliwungu}

Secara etimologis, kata manajemen berasal dari bahasa inggris "management", yang berarti ketatalaksanaan, tata pimpinan, dan pengelolaan. Artinya, manajemen adalah sebagai suatu proses yang diterapkan oleh individu atau kelompok dalam upaya-upaya koordinasi untuk mencapai suatu tujuan (Munir dan Ilahi, 2006: 9).

Dalam bahasa arab, istilah manajemen diartikan sebagai "annizam" atau “at-tanzhim”, yang merupakan suatu tempat untuk menyimpan segala sesuatu dan penempatan segala sesuatu pada tempatnya. Dalam skala aktivitas juga dapat diartikan sebagai aktivitas menerbitkan, mengatur, dan berpikir yang dilakukan oleh seseorang, sehingga ia mampu mengemukakan, menata, dan merapikan segala sesuatu yang ada disekitarnya, megetahui prinsipnya serta menjadikan hidup selaras dan serasi dengan lainnya. 
Secara terminologi para ahli mendefinikan manajemen sebagai sebuah proses perencanaan, pengorganisasian, pengaturan terhadap para anggota organisasi serta penggunaan seluruh sumber-sumber yang ada secara tepat untuk meraih tujuan organisasi yang telah ditetapkan Munir dan Ilahi, 2006: 9). Kemudian, Hamriani (2013: 24-244) dalam penelitiannya mengartikan manajemen adalah serangkaian kegiatan yang dilakukan untuk mengefisienkan dan mengefektifkan pencapaian tujuan organisasi melalui pemanfaatan sumber daya manusia dan sumber daya lainnya yang dibutuhkan.

Selain itu, Robert Kreitner dalam Wahidin Saputra (2012: 284) manajemen adalah sebagai suatu proses kerja melalui orang lain untuk mencapai tujuan organisasi dalam lingkungan yang berubah. Secara sederhana menurut hemat penulis, manajemen merupakan suatu aktivitas yang berpusat pada efektifitas dan efisiensi penggunaan sumber daya manusia untuk mencapai tujuan tertentu dalam sebuah organisasi. Hal ini menunjukkan perlunya manajemen dalam menjalankan pengorganisasian dalam suatu lembaga atau organisasi.
Adapun pengorganisasian (altanzhim) merupakan seluruh proses pengelompokan orang-orang, alat-alat, tugas-tugas, tanggungjawab, dan wewenang sedemikian rupa sehingga tercipta suatu organisasi yang dapat digerakkan sebagai suatu tujuan yang telah ditentukan (Munir dan Ilahi, 2006: 117). Pengorganisasian dalam pandangan islam bukan semata-mata merupakan wadah, akan tetapi lebih menekankan bagaimana pekerjaan dapat dilakukan secra rapi, teratur, dan sistematis. Hal ini diilustrasikan dalam QS. Ash-Shaff [61]: 4

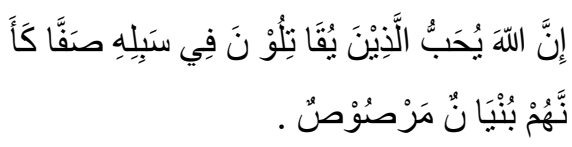

Artinya: "Sesungguhnya Allah menyukai orang-orang yang berperang di jalanNya dalam barisan yang teratur seakan-akan seperti bangunan yang tersusun kokoh."

Pada proses pengorganisasian ini akan menghasilkan sebuah rumusan struktur organisasi dan pendelegasian wewenang dan tanggung jawab. Hal ini sangat tepat diaplikasikan dalam lembaga dakwah yang harus memiliki manajemen pengorganisasian yang rapi, teratur, dan sistematis agar tugas da'i 
selaku pegiat dakwah dapat berjalan sesuai dengan tujuan yang ditetapkan.

MWC NU (Majelis Wakil Cabang Nahdlatul Ulama) merupakan struktur kepengurusan organisasi NU yang berkedudukan di tingkat kecamatan. MWC NU kecamatan Kaliwungu merupakan salah satu organisasi NU yang berkedudukan di tingkat kecamatan di kabupaten Kendal yang masih terjaga eksistensinya untuk melestarikan, mengembangkan dan mengamalkan ajaran islam Ahlussunnah wal Jamaah. Pada khususnya, MWC NU Kaliwungu menjadi penggerak dakwah amar ma'ruf nahi munkar dengan menganut ajaran islam yang berdasarkan empat madzab untuk terwujudnya masyarakat Kaliwungu yang demokratis, berkeadilan, dan demi kesejahteraan umat di wilayah Kaliwungu serta wilayah kabupaten Kendal pada umumnya.

Majelis Wakil Cabang Nahdlatul Ulama (MWC NU) kecamatan Kaliwungu, dalam menjalankan organisasi dakwah sejalan dengan tujuan organisasi, maka langkah pertama yang disusun adalah membentuk struktur organisasi dan menetapkan program kerja selama 1 periode (masa khidmah 5 tahun).
Struktur lembaga kepengurusan MWC

NU Kaliwungu terdiri dari Mustasyar

(Penasihat), Syuriah (Pimpinan Tertinggi), dan Tanfidziyah (Pelaksana). Selain itu, juga memiliki seperangkat Badan Otonom (Banom), Lajnah, dan lembaga yang bergerak pada bidang tertentu sesuai dengan tugasnya masing-masing. Adapun penyusunan program kerja disesuaikan dan ditentukan oleh masing-masing lembaga yang terdapat dalam kestrukturan MWC NU Kaliwungu.

MWC NU Kaliwungu dalam mengembangkan tugas-tugas dakwahnya menerapkan manajemen pengorganisasian berdasarkan bentukbentuk pembagian tugas yang meliputi spesialisasi kerja, departementalisasi dakwah, rantai komando, rentang kendali, sentralisasi dan desentralisasi, serta formalisasi dakwah (Munir dan Ilahi, 2006: 120-131).

Berdasarkan teori tersebut, dalam menjalankan aktivitas dakwah di wilayah Kaliwungu Rois 'Amm MWC NU Kaliwungu sudah menerapkam tugas, wewenang dan tanggung jawabnya berdasarkan bentuk-bentuk pengorganisasian sebagai berikut:

\section{a. Spesialisasi Kerja dalam MWC NU Kaliwungu}


MWC NU dalam membagi tugas kerja (Spesialisasi Kerja) berdasarkan struktur kepengurusan yang terdiri dari mustasyar (penasihat), syuriah (pimpinan tertinggi), tanfidziyah (pelaksana).

Mustasyar (penasihat) tugasnya adalah memberikan nasihat kepada pengurus MWC NU. Syuriah (pemimpin tertinggi) tugasnya pembina, pengendali, pengawas, dan penentu kebijakan di MWC NU. Sedangkan tanfidziyah (pelaksana) tugasnya adalah melaksanakan program kerja dan memimpin jalannya organisasi, serta menyampaikan laporan secara periodik kepada pengurus syuriah.

Hal tersebut menunjukkan bahwa dalam pengorganisasian di MWC NU terdapat spesialisasi kerja yang jelas antara Ketua Umum (Rois 'Amm/Rois Syuriah) yang menentukan kebijakan organisasi serta dewan Tanfidziyah selaku pelaksana kegiatan organisasi berdasarkan program kerja yang telah direncanakan untuk mencapai tujuan dari organisasi.

b. Departementalisasi dalam MWC NU Kaliwungu

Berikut merupakan bentuk departementalisasi Lembaga- lembaga dalam MWC NU Kaliwungu:

1. Lembaga Dakwah NU (LDNU)
a. Ust. Lukman Hakim
b. Ust. Mujahidin, BA
c. H. Ali Muhtar, Lc, MA

2. Lembaga Pendidikan Ma'arif NU (LP Ma'arif)
a. Abdul Ghofur, S.Pd, M.Pd
b. Ky. Abdul Ghofur
c. Abu Mansyur

3. Lembaga Pengenbangan pertanian NU (LP2 NU)
a. Anharul Asror
b. Ach Mughni
c. Ir. Eko Tri Djatmiko

4. Lembaga Perekonomian NU (LP NU)
a. Bambang Sri Hartono, SE,M.Si
b. H. Wahidin Yunus
c. Ust. Abdul Aziz Asrof

5. Lembaga Kemaslahatan Keluarga NU (LKK NU)
a. Wachidin Rohmad
b. Abdul Azis
c. M. Erwin Saputro, S.Pd

6. Lembaga Amil Zakat, Infaq dan Shadaqah NU (LAZIZ $\mathrm{NU})$

\section{a. Nasrun Yunus}



b. Ust. Sonhaji
c. H. Saeful Hadi, S.Ag

7. Lembaga Seni Budaya Muslim Indonesia (LESBUMI)
a. H. Khomsan Hamdan
b. Ky. Hifni Effendi
c. Ust. Ichsan M.

8. Lembaga Bathsul Masail NU (LBM NU)

\section{a. Ust. M. Amdad Mukhlas}

b. Ust. Abdus Salam

c. Ust. Amin Ridwan

Abah KH. Fauzi Shodaqoh selaku Rois 'Amm (pimpinan tertinggi) menuturkan bahwa dalam menentukan calon pengurus terlebih dahulu dilakukan filterisasi kepada para kader penggerak yang bakal menjadi calon pengurus anggota dalam setiap lembaga yang ada. Beliau bersama dewan Tanfidziyah membentuk struktur organisasi kepengurusan lembaga dengan bertolak pada keahlian dan profesionalisme anggota yang kemudian dimasukkan ke dalam struktur kepengurusan yang disesuaikan pada bidang keahlian masing-masing anggota.

Misalnya dalam menentukan koordinator pada Lembaga Dakwah
NU (LDNU) anggota yang berada dalam struktur kepengurusan merupakan para da'i yang kharismatik, mahir, mumpuni dan profesional yang telah memiliki jam terbang dakwah yang telah melalang buana dalam dunia dakwah. Begitu pula dengan lembaga-lembaga (departemen) yang lain juga pengelompokkannya berdasarkan fungsi dan tugas masing- masing untuk mencapai tujuan yang diharapkan (Wawancara Sabtu, 3 Juli 2021 pukul 16.00 wib).

\section{c. Rantai Komando dalam MWC NU Kaliwungu}

Rantai komando dalam menjalankan wewenang, tanggung jawab dan komando dilakukan dalam kegiatan rutinan setiap selapan sekali (35 hari) pada hari Senin malam Selasa manis sebagai bentuk pemberdayaan anggota dari pihak pengurus, lembaga, dan banom-banom pada semua lapisan baik tingkat ranting maupun anak ranting. Acara meliputi manaqiban, tahlilan, tadarusan dan amalanamalan ahlussunnah wal jamaah lainnya serta dialog yang berguna untuk mengatasi masalah-masalah yanng menjadi kendala dari setiap 
pengurus, lembaga dan para banom dalam menjalankan tugas dan wewenang dalam pengorganisasian.

Adapun langkah-langkah rantai komando dalam mengambil keputusan pemecahan masalah bersumber dari dewan penasehat (Mustasyar) melalui pimpinan tertinggi (Syuriah) kepada ketua pelaksana (Tanfidziyah). Kemudian diteruskan kepada para kordinator pengurus dan lembaga yang kemudian ditembuskan kepada anggota masing-masing pengurus maupun lembaga untuk menyelesaikan masalah yang terjadi dan melanjutkan tugas sesuai tanggung jawabnya.

\section{d. Rentang Kendali dalam} Organisasi MWC NU Kaliwungu

Penentuan rentang kendali di MWC NU Kaliwungu telah disepakati dalam penetapan program kerja di awal, karena yang menjadi kendala dalam kepengurusan MWC NU Kaliwungu adalah banyak dari para pengurus dan anggota yang masuk dalam struktur kepengurusan Masjid Agung Al-Muttaqin Kaliwungu. Oleh karena itu, ketika terjadi kesamaan event atau kegiatan secara bersama-sama telah di antisipasi oleh dewan pelaksana kepada pengurus lain yang telah mendapat amanat untuk mengambil kendali sesuai dengan mandat/perintah kepada pemegang kendali untuk mengambil keputusan.

\section{e. Sentralisasi dan Desentralisasi dalam MWC NU Kaliwungu}

Sentralisasi dan desentralisasi berjalan secara kondisional dan aplikatif, sehingga ketika dalam pelaksanaannya terdapat hambatan atau halangan yang brekembang maka, dapat dialihkan kepada pihak lain untuk memberikan alternatif pemecahan masalah dan wewenang melalui musyawarah mufakat/ kesepakat yang telah diputuskan oleh Rois 'Amm bersama ketua Tanfidziyah serta para jajaran pengurus. Misalnya, ketika terjadi insiden musholla muhammadiyah yang dijadikan tempat sholat berjamaah oleh kaum ras muhammadiyah maka, ketika Abah Fauzi (Rois 'Amm) sedang berada di luar kota mengikuti kongres, beliau mengutus da'i yang sangat berpengaruh di wilayah Kaliwungu 
untuk menghentikan kegiatan tersebut yanng di anggap melanggar syariat agama. Da'i yang di tunjuk pun merupakan tokoh masyarakat fenomenal Kaliwungu yang memahami betul permasalahan yang di hadapi.

\section{f. Formalisasi dalam MWC NU}

\section{Kaliwungu}

Para da'i yang dipilih dalam struktur kepengurusn dalam Lembaga Dakwah NU (LDNU) merupakan da'i- da'i pilihan yang ahli dibidang ilmu agama secara keseluruhan baik dalam bidang ibadah, muamalah, aqidah, akhlak, tata bahasa (balaghah), mantiq dan lain-lain. Para da'i tersebut berasal dari latar belakang pendidikan agama yang sangat tinggi sehingga pemahaman tentang nilai-nilai keagamaan telah di luar kepala baik yangn menempuh pendidikan secara klasikal maupun yang menempuh pendidikan di Timur Tengah. Jadi, para da'i yang di terjunkan dalam masyarakat tidak dapat diragukan lagi kadar skill dan profesionalitasnya dalam ranah dakwah islam.

Dengan demikian, MWC NU kecamatan Kaliwungu dalam menjalankan aktivitas dakwah di wilayah Kaliwungu berpedoman pada manajemen pengorganisasian dakwah sehingga merumuskan pendelegasian wewenang dan tanggung jawabnya sebagai lembaga dakwah.

\section{Strategi Lembaga Dakwah NU} (LDNU) MWC NU Kaliwungu dalam

\section{Mengatasi Tantangan Globalisasi}

Strategi merupakan suatu rencana tindakan termasuk penggunaan metode dan pemanfaatan berbagai sumber daya atau kekuatan (Hasan, 2018: 76). Jadi, strategi merupakan proses perencanaan dan belum berbentuk tindakan. Dalam aktivitasnya, dakwah juga membutuhkan metode siasat, taktik atau manuver yang disering disebut dengan strategi dakwah (Ulfah, 2015: 209). Sebagai suatu lembaga atau organisasi dakwah perlunya menetapkan strategi dalam mewujudkan tujuan yang telah direncanakan. Hal ini berhubungan dengan kegiatan amar ma'ruh nahi mungkar.

Dewasa ini tantangan dakwah islam berkaitan dengan akses globalisasi dan kenyataan pluralitas agama. Kemajuan IPTEK yang pesat telah mentransformasikan peradaban manusia dari kultur pertanian ke industri. Godaan dunia dan permasalahan umat yang semakin 
kompleks, mengharuskan praktisi dakwah untuk memberikan alternatif pemecahan masalah secara efektif dan efisien. Oleh karena itu, dibutuhkan strategi yang mumpuni dalam mengatasi berbagai macam tantangan dakwah.

Strategi dakwah yang dilakukan lebih bersifat penguatan kembali ajaran ke-NU-an dan ke-Aswaja-an kepada masyarakat Kaliwungu dan sekitarnya, mengingat pasar industri global yang mulai merambah di wilayah Kaliwungu yaitu berdirinya KIK (Kawasan Industri Kendal). Menurut beliau Rois Syuriah MWC NU Kaliwungu (KH. Fauzy Shodaqoh), Kaliwungu merupakan sebagai kecamatan perbatasan yang menjadi wajah pertama cerminan kabupaten Kendal. Hal ini yang menjadikan keresahan dan kekhawatiran para tokoh masyarakat yang tergabung dalam kepengurusan MWC NU Kaliwungu, sebabnya karena peluang masuknya kebudayaan barat akan lebih mudah masuk menggerogoti akhlak masyarakat Kaliwungu khususnya dan kabupaten Kendal umumnya.

Identitas Kaliwungu yang notabene Kota Santri akan luntur, tradisi khas dan budaya kental di Kaliwungu di rasa akan punah jika tidak tetap dipertahankan. Oleh karena itu, para ulama menyusun strategi dakwah yang lebih efektif dan efisien melihat permasalahan yang sedang terjadi melalui kegiatan penguatan mental dan spiritual dengan 1 Miliyar Sholawat bersama masyarakat di msing-masing ranting, mengadakan Lailatul Ijtima' secara berkala bersama para tokoh pemuka agama diwilayah KaliwunguKendal, dan pemanfaatan media dakwah dengan menjalin kerjasama dengan Radio Citra Kendal untuk dialih tempatkan di Gedung Dakwah MWC NU. Pemanfaatan Gedung Dakwah MWC NU untuk kegiatan sekolahsekolah dari KB, TK, MI, MTS dan Aliyah dibawah LP. Ma'arif NU untuk mengembangkan bakat minatnya disana.

\section{Kesimpulan}

Berdasarkan hasil wawancara bersama abah KH. Fauzi Shodaqoh selaku Rois Syuriah MWC NU Kaliwungu, mendapatkan hasil gambaran pengorganisasian yang berada dalam organisasi NU di tingkat kecamatan Kaliwungu yaitu MWC (Majelis Wakil Cabang) sesuai dengan konsep teori pengorganisasian dalam buku yang berjudul "Manajemen Dakwah" karya M. Munir dan Wahyu 
Ilaihi terbitan Kencana. Dimana bentukbentuk pengorganisasian dari spesialisasi kerja, departementalisasi, rantai komando, rentang kendali, sentralisasi dan desentralisasi, formalisasi, serta strategi dakwah diterapkan secara apik dan terstruktur berjalan sesuai fungsional dari lembaga dakwah melalui organisasi sehingga dapat berjalan mencapai tujuan yang hendak dijalankan.

Adapun strategi dakwah yang dilakukan MWC NU Kaliwungu dalam menghadapi pasar industri global yang mulai merambah di wilayah Kaliwungu yang ditandai dengan berdirinya KIK (Kawasan Industri Kendal), lebih bersifat kepada penguatan kembali ajaran ke-NU-an dan ke-Aswaja-an kepada masyarakat. Oleh karena itu, para ulama menyusun strategi dakwah yang lebih efektif dan efisien melihat permasalahan yang sedang terjadi melalui kegiatan penguatan mental dan spiritual dengan 1 Miliyar Sholawat bersama masyarakat di msing-masing ranting, mengadakan Lailatul Ijtima' secara berkala bersama para tokoh pemuka agama diwilayah KaliwunguKendal, dan pemanfaatan media dakwah dengan menjalin kerjasama dengan Radio Citra Kendal untuk dialih tempatkan di Gedung Dakwah MWC NU.

\section{Daftar Pustaka}

Ahmad, Nur. "Tantangan Dakwah di Era Teknologi dan Informasi: Formulasi Karakteristik, Popularitas, dan Materi di Jalan Dakwah". Jurnal Addin, Vol. 8 (2). 2014. Hlm. 319-344.

Alfian. "Mananjemen Perencanaan Dakwah". Jurnal Manajemen Dakwah. 2018. Hlm. 71-77.

Anwar, Ahmad Misbahul. "Peran Organisasi dalam Dakwah". Junal Bina Umat, Vol. 2 (2). 2019. Hlm. 59-77.

Basri, Hasan. "Manajemen Organisasi Dakwah". Jurnal Al-Munzir, Vol. 9 (1). 2016. Hlm. 113-130.

Darojah. Startegi Dakwah Majelis Taklim Istighotsah MWC NU Kecamatan Wonotunggal Kabupaten Batang. Thesis (Undergraduate S1). Semarang: Fakultas Dakwah dan Komunikasi UIN Walisongo. 2016.

Hamriani, "Organisasi dalam Manjemen Dakwah”. Jurnal Dakwah Tabligh, Vol. 14 (2). 2013. Hlm. 239-249.

Hasan, Ridwan. "Kontribusi dan Strategi Metode Dakwah di Era Globalisasi". Jurnal Peurawi, Vol. 1 (2). 2018. Hlm. 69-81.

Machasin. Psikologi Dakwah Suatu Pengantar Studi. Semarang: CV. Karya Abadi Jaya. 2015.

Moleong, Lexy J. Metodologi Penelitian Kualitatif Edisi Revisi. Bandung: PT. Remaja Rosdakarya. 2016.

Munir, M. dan Ilahi, Wahyu. Manajemen Dakwah. Jakarta: Kencana. 2006.

Saputra, Wahidin. Pengantar Ilmu Dakwah. Cet. II; Jakarta: Rajawali Pers, 2012. 
Sudaryono. Metodologi Penelitian

Kuantitatif, Kualitatif dan Mix Method Edisi Kedua. Depok: Rajawali Pers. 2019.

Sugiyono. Metode Penelitian Kombinasi (Mixed Methods). Bandung: Alfabeta. 2018.

Ulfah, Novi Maria. "Strategi dan Manajemen Dakwah Lembaga Dakwah Islam Indonesia (LDII) Kecamatan Tugu Kota Semarang". Jurnal Ilmu dakwah, Vol. 35 (2). Juli - Desember 2015 ISSN 1693-8054. Hlm. 207-224.

Wawancara bersama Rois Syuriah MWC $N U$ Kaliwungu, di kediaman beliau ds. Krajankulon, pada hari Sabtu, 3 Juli 2021, pukul 16.00$16.30 \mathrm{Wib}$. 